Електронне наукове фахове видання з економічних наук «Modern Economics», №15 (2019), 183-190 https://modecon.mnau.edu.ua | ISSN 2521-6392

УдК 658.8:004

DOI: https://doi.org/10.31521/modecon.V15(2019)-26

Сухомлин Л. В., кандидат технічних наук, доцент, доцент кафедри менеджменту, Кременчуцький національний університет імені Михайла Остроградського, м. Кременчук, Україна

ORCID ID: 0000-0001-9511-5932

e-mail: larisavad@gmail.com

Орлова К. О., магістрант кафедри менеджменту, Кременчуцький національний університет імені Михайла Остроградського, м. Кременчук, Україна

ORCID ID: 0000-0001-8467-4608

e-mail: katya.orlova.977@gmail.com

Інформаційно-програмні рішення щодо удосконалення збутової діяльності підприємства

Анотація. Статтю присвячено комплексній оцінці показників збутової діяльності, а також наданню практичних рекомендацій щодо удосконалення системи збуту із застосуванням інформаційно-програмного забезпечення для підприємств гірничодобувної галузі. Надано інтерпретацію понять «збут», система збуту та канали дистрибуції із точки зору різних авторів. Встановлено, що одним із пріоритетних завдань для розвитку збутової діяльності та побудови ефективної системи збуту металургійних підприємств є впровадження інформаційних технологій. Завдяки моделі SNW-аналізу підприємства досліджено основні канали збуту залізорудної продукції, що дозволило виявити резерви удосконалення збутової діяльності, а також надати практичні рекомендації у розрізі кожного з існуючих каналів шляхом прийняття інформаційно-програмних рішень у сучасних ринкових умовах господарювання.

Ключові слова: збут продукції; канали дистрибуції; SNW-аналіз; маркетингові комунікації; SEО-оптимізація; CRM-система.

Sukhomlyn Larysa, Candidate of Technical Sciences, Associate Professor, Associate Professor at the Department of Management, Kremenchuk Mykhailo Ostrohradskyi National University, Kremenchuk, Ukraine

Orlova Kateryna, master student at the Department of Management, Kremenchuk Mykhailo Ostrohradskyi National University, Kremenchuk, Ukraine

\title{
Information and Software Solutions for the Improvement of Enterprise Sales Activity
}

Abstract. Introduction. Sales of manufactured products are an integral part of industrial-sector activities in a market economy. At present, enterprise finances directly depend on the efficient building of sales processes. If there is tough competition, the main sales management task is to ensure that the organization conquers and maintains its preferred market share and to achieve superiority over its competitors. For successful sales functioning, a set of measures is needed, associated with an increase in the markets for products consumers from sales activities in general, as well as for each distribution channel.

The purpose of the article is to develop practical recommendations for improving sales activities of the metallurgical enterprise, aimed at attracting new consumers through the use of modern information and software.

Results. The theoretical description of the concept of «sales» was provided in both narrow and broad aspects. In the field of commercial activity, three main stages of sales were allocated to industrial enterprises. It was determined that effective marketing policy promotes high level of competitiveness of the enterprise in the world market. An analysis of the Ukrainian metallurgical enterprise PJSC «Poltava GOK» sales activity was carried out. Thanks to the SNW analysis model, the main channels of iron ore products were defined. Through the conducted research, areas for improvement of sales activity by means of applying SEO-optimization and CRM-system were found. The benefit of the proposed measures is confirmed by the calculation of net income from their implementation.

Conclusions. The overall enterprise turnover, its growth, the rate, profit amount and the control degree of the manufacturer's firm over bringing its products to the final consumer depend on the size of the sales network and its effectiveness. Enterprises work in the new economic conditions implies a complete transformation of all enterprise functional areas and this should mainly concern sales activities. The subject of this article is very relevant, since the sales system is the final stage in all of the enterprise's activities of creating, producing and bringing goods to the consumer.

Keywords: sales system; distribution channels; marketing communications; SEO-optimization; CRM-system.

JEL Classification: L 22; L 71; P 33; C 88.

Постановка проблеми. Підприємствам гірничодобувної промисловості у процесі управління збутовою діяльністю доводиться розв'язувати безліч завдань. Основним із них $\epsilon$ збільшення обсягу продажів внаслідок підвищення рівня обслуговування споживачів. Для того, щоб досягти ефективності в процесі управління збутовою діяльністю підприємства, необхідно створити таку систему управління, яка б

Стаття надійшла до редакції: 26.05.2019

Received: 26 May 2019 
реалізовувала цілі та стратегії збуту, орієнтовані на потреби кінцевого споживача [1, с. 129]. Отже, виникають питання, як ефективно задовольнити зовнішній попит за термінами, обсягами, якістю та сервісним обслуговуванням. Розв'язання цих питань $€$ можливим за рахунок організації оптимальної взаємодії виробництва та збуту. Для успішного функціонування системи збуту необхідний комплекс рішень, пов'язаний зі збільшенням ринків споживачів продукції у цілому, а також по кожному каналу розподілу. Доцільним $є$ застосування інформаційнопрограмних рішень.

Аналіз останніх досліджень і публікацій. Аналіз проблем і результати досліджень, які пов'язані 3 різноманітними аспектами збутової діяльності підприємств, знайшли відображення у працях багатьох вітчизняних та зарубіжних науковців, серед яких І. Абрамович, В. Алькема, Л. Балабанова, Ю. Кашуба, Ю. Огерчук, О. Сумець, Я. Янишин та інші [2, с. 2].
Сучасна економічна наука приділяє значну увагу інформатизації збутової діяльності. Вона аналізується в наукових працях В. Рожнова, В. Завгородного, В. Дика, А. Іоффе, А. Щедріна, Л. Винарика [3, с. 5].

Формулювання цілей дослідження. Головною метою статті $\epsilon$ надання практичних рекомендацій щодо удосконалення збутової діяльності металургійних підприємств, спрямованих на залучення нових споживачів по кожному каналу дистрибуції за рахунок застосування інформаційно-програмних рішень.

Виклад основного матеріалу дослідження. Функціонування сучасних металургійних підприємств у нових економічних умовах передбачає повне перетворення функціональних сфер їх діяльності, що головним чином стосується збуту продукції. У табл. 1 розглянуто основні визначення поняття «збут», що наведені авторами у своїх наукових працях.

Таблиця 1 Визначення терміну «збут» у науковій літературі

\begin{tabular}{|c|l|}
\hline Автор & \multicolumn{1}{c|}{ Визначення } \\
\hline \multirow{2}{*}{ Балабанова Л. } & $\begin{array}{l}\text { «збутуширокому розумінні-процес організації транспортування, складування, підтримки запасів, } \\
\text { доробки, просування до оптових та роздрібних торговельних ланок, передпродажної підготовки, } \\
\text { упивання та реалізації товарів з метою задоволення потреб покупців і отримання на цій основі } \\
\text { покупця, спрямований на отримання прибутку, і такий, що вимагає знань, навичок і певного рівня } \\
\text { торговельної компетенції» }\end{array}$ \\
\hline Надтока Т., & $\begin{array}{l}\text { Це комплекс принципів, методів та заходів, що використовується керівництвом для організації та } \\
\text { управління збутовою діяльністю підприємства з метою забезпечення ефективних продажів товарів } \\
\text { в межах визначених цільових ринків }\end{array}$ \\
\hline Наумов Н. & Підзбутом розуміють сукупність заходів, які відбуваються після виходу за межі території виробника \\
\hline Фальцман В. & збут як перетворення виробничих товарів та послуг у прибуток \\
\hline Бєлінський П. & $\begin{array}{l}\text { процес просування готової продукції на ринок та організації товарного обміну з метою отримання } \\
\text { підприємницького прибутку }\end{array}$ \\
\hline
\end{tabular}

Джерело: систематизовано авторами на основі [4, с.117; 5, с.77; 6, с. 189]

Створюючи систему збуту та орієнтуючись на запити покупців, виробник набуває значної переваги у конкурентній боротьбі. Під час процесу збуту ефективніше відбувається аналіз і вивчення смаків та уподобань споживачів. У наукових працях учених в області комерційної діяльності можна виділити три основні етапи збуту. Зміст кожного з них наведено у табл. 2.

Таблиця 2 Основні етапи збуту продукції підприємства

\begin{tabular}{|l|l|}
\hline \multicolumn{1}{|c|}{ Етап } & \multicolumn{1}{|c|}{ Характеристика } \\
\hline & 1.1 інформування, встановлення контакту; \\
1. Пошук покупців & 1.2 робота з новим клієнтом; \\
& 1.3 формування портфеля замовлень. \\
\hline & 2.1 укладення угоди (договору, контракту) і виконання замовлень; \\
& 2.2 обробка замовлень; \\
& 2.3 акумуляція; \\
2. Організація & 2.4 відвантаження та транспортування товару; \\
опрацювання та & 2.5 оплата замовлення та зміна власника товару; \\
виконання замовлень & 2.6 операції з навантаження і розвантаження товару; \\
& 2.7 організація складування; \\
& 2.8 зберігання та регулювання товарних запасів; \\
& 2.9 упаковка, фасування. \\
\hline 3. Етап післяпродажного & 3.1 робота з претензіями; \\
обслуговування & 3.2 підтримка взаємин з клієнтами; \\
& 3.3 продаж додаткових товарів / сервісів. \\
\hline
\end{tabular}

Джерело: систематизовано авторами 
Реалізація продукції передбачає використання посередників, унаслідок чого формуються канали розподілу [7, с. 62]. Виділяють три основні класифікаційні ознаки збутової діяльності:

1. По організації системи збуту:

- прямі канали (безпосередня реалізація продукції конкретному споживачеві);

- непрямі канали (використання незалежних торгових посередників);

- комбіновані канали (використання представництв підприємства).

2. Залежно від кількості посередників:
- інтенсивні (велике число оптових посередників; мета: розширення збуту, наближення товару до споживача);

- селективні (обмежене число посередників; мета: досягнення великого обсягу продажів при збереженні контролю над капіталом збуту);

- ексклюзивні (один або невелике число посередників; мета: збереження престижного іміджу).

3. За рівнем та методом:

- традиційні;

- вертикальні;

Прогресивна модель зв'язків у каналі дистрибуції формується за умов вертикальної інтеграції (рис. 1).

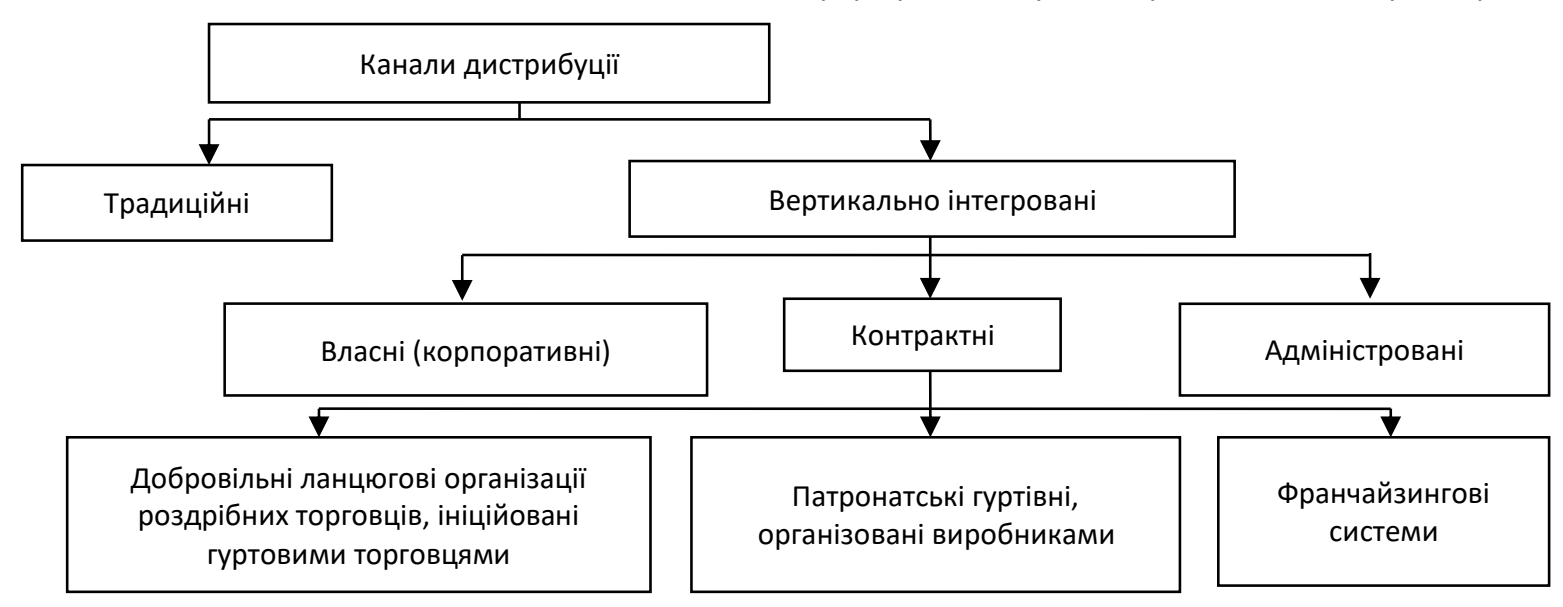

Рисунок 1 - Традиційні і вертикально інтегровані канали дистрибуції

Джерело: [9, с. 119]

Об'єктом дослідження $€$ комплексний аналіз зовнішньоекономічної діяльності ПрАТ «Полтавський ГЗК» на основі застосування інформаційних рішень. ПрАТ «Полтавський ГЗК» позиціонується як виробник високоякісних залізорудних окатишів (рис. 2) [8, с. 17].
Основним видом продукції є залізорудні офлюсовані окатиші [9, с. 110]. До переліку класифікатора також занесений 81 додатковий напрям діяльності підприємства, що пов'язано із техобслуговуванням, ремонтом автомобілів та передачею електроенергії.

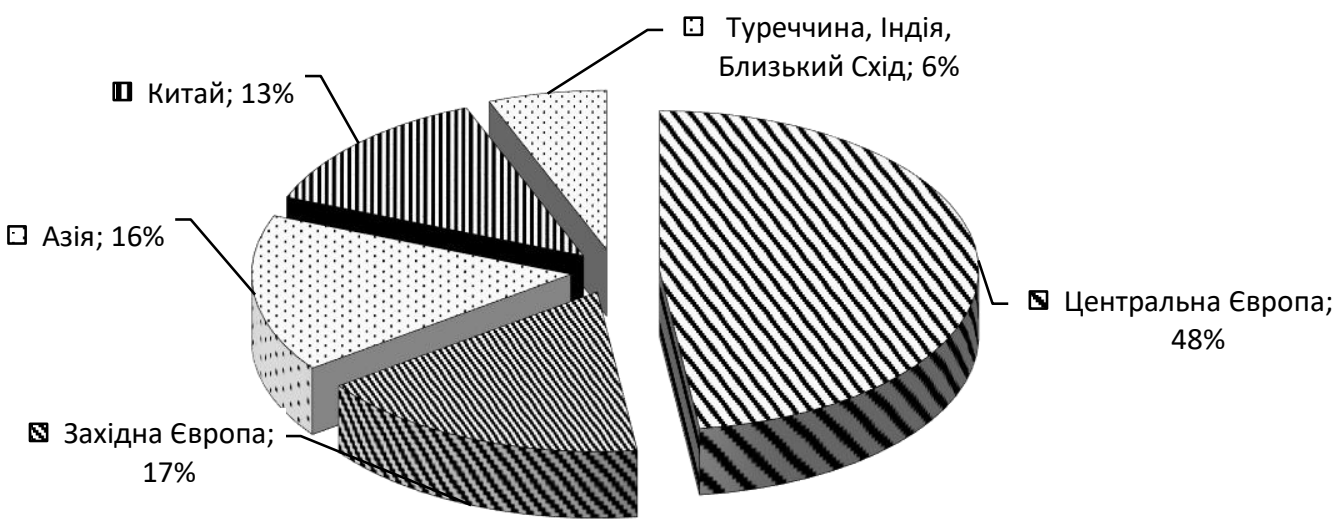

Рисунок 2 - Збут окатишів ПрАТ «Полтавський ГЗК» (2018р.)

Джерело: срормовано авторами

Ефективність функціонування підприємства визначена на основі SNW-аналізу (табл. 3). 
Електронне наукове фахове видання з економічних наук «Modern Economics», №15 (2019), 183-190 https://modecon.mnau.edu.ua | ISSN 2521-6392

Таблиця 3 SNW-аналіз діяльності ПрАТ «Полтавський ГЗК»

\begin{tabular}{|c|c|c|c|}
\hline Фактор підприємства & Значення & Вагомість & Результат \\
\hline \multicolumn{4}{|c|}{ 1. організація виробництва } \\
\hline 1.1 місцезнаходження відносно ринку збуту & +3 & 0,10 & 0,3 \\
\hline 1.2 структура управління & +2 & 0,10 & 0,2 \\
\hline \multicolumn{4}{|c|}{ 2. маркетинг } \\
\hline 2.1 місце на ринку & +1 & 0,08 & 0,8 \\
\hline 2.2 маркетингова концепція & -2 & 0,06 & $-0,12$ \\
\hline 2.3 просування & -2 & 0,08 & $-0,16$ \\
\hline \multicolumn{4}{|c|}{ 3. персонал } \\
\hline 3.1 структура працівників & +2 & 0,08 & 0,16 \\
\hline 3.2 кількісний кадровий склад & 0 & 0,06 & 0 \\
\hline 3.3 система мотивації персоналу & +2 & 0,08 & 0,16 \\
\hline \multicolumn{4}{|c|}{ 4. система збуту } \\
\hline 4.1 асортимент продукції & +4 & 0,07 & 0,28 \\
\hline 4.2 цінова політика & +2 & 0,05 & 0,1 \\
\hline 4.3 методи стимулювання збуту & -3 & 0,08 & $-0,24$ \\
\hline \multicolumn{2}{|l|}{ Усього: } & 1 & 0,78 \\
\hline
\end{tabular}

Джерело: складено авторами

У результаті використання SNW-аналізу при оцінці зовнішнього середовища організація може усунути свої слабкі сторони [10, с. 29]. Кожен із факторів було кількісно оцінено від «-5» (дуже погано) до «+5» (дуже добре) за допомогою методу експертних оцінок. Для підвищення ефективності проведення дослідження були введені вагові коефіцієнти. Результати свідчать, що більшість чинників мають позитивне значення.

Для аналізу ефективності зовнішньоекономічної діяльності ПрАТ «Полтавський ГЗК» доцільно розглянути динаміку виручки, валового та чистого прибутку за три попередні роки, а також показник рентабельності інвестицій:

$$
R O S=\frac{E B I T}{S A L E S} * 100 \%,
$$

де ЕВIT - операційний прибуток (до сплати податків і відсотків);

SALES -виручка від реалізації продукції.

Розрахунки рентабельності підприємства наведені у табл. 4.

Таблиця 4 Показники виручки та прибутку ПрАТ «Полтавський ГЗК»

\begin{tabular}{|c|c|c|c|c|}
\hline Період & $\begin{array}{c}\text { Виручка, } \\
\text { тис грн }\end{array}$ & $\begin{array}{c}\text { Валовий прибуток, } \\
\text { тис грн }\end{array}$ & $\begin{array}{c}\text { Чистий прибуток, } \\
\text { тис грн }\end{array}$ & $\begin{array}{c}\text { Рентабельність, } \\
\%\end{array}$ \\
\hline 2015 & 14969052 & 5923879 & 4442909 & 29,68 \\
\hline 2016 & 16946256 & 7920047 & 5940036 & 35,05 \\
\hline 2017 & 20378679 & 11098586 & 8323939 & 40,85 \\
\hline
\end{tabular}

Джерело: розраховано із використанням фінансової звітності підприємства

Схематично проаналізовані показники представлені на рис. 3.

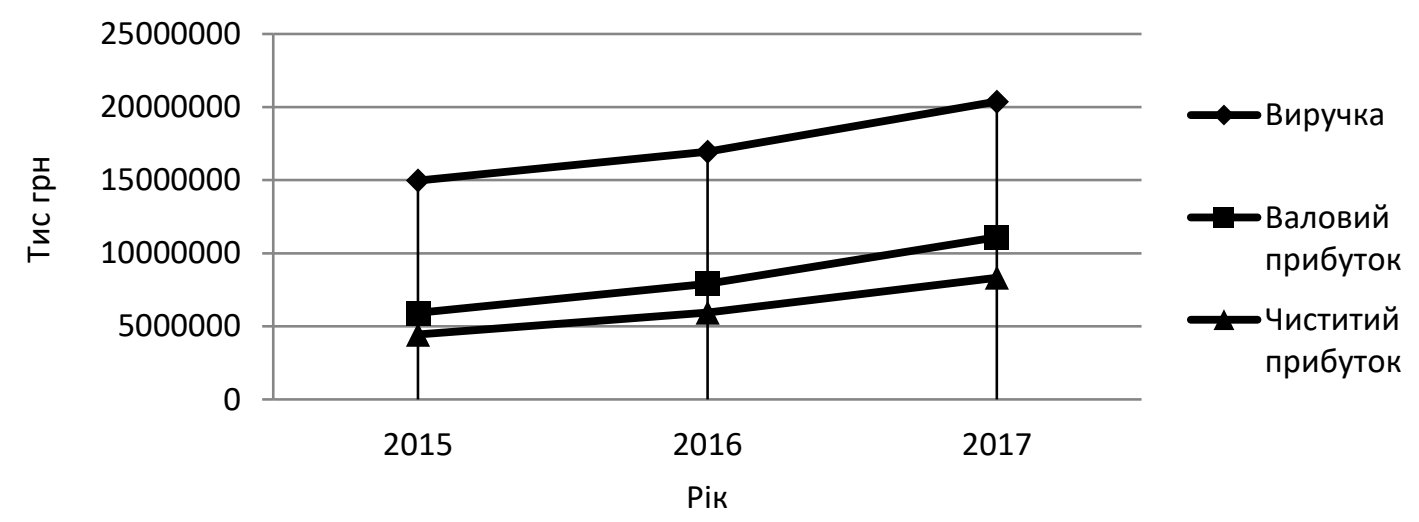

Рисунок 3 - Показники виручки та прибутку ПрАТ «Полтавський ГЗК»

Джерело: розроблено авторами на основі табл. 4 
Отже, ПрАТ «Полтавський ГЗК» стабільно функціонує на зовнішньому ринку, оскільки за останні три роки коливання оцінюваних показників незначні, а рентабельність при цьому варіюється від $29 \%$ до майже $41 \%$, що $є$ високим показником. Основними каналами збуту підприємства $€$ прямий продаж юридичним та фізичним особам. Логістичні потоки розподілені за трьома напрямками - порт Південний, порт Ізмаїл, західний кордон - у співвідношенні 50 \% : $20 \%$ : 30\%. Найпоширеніші канали збуту представлені на рис. 4.

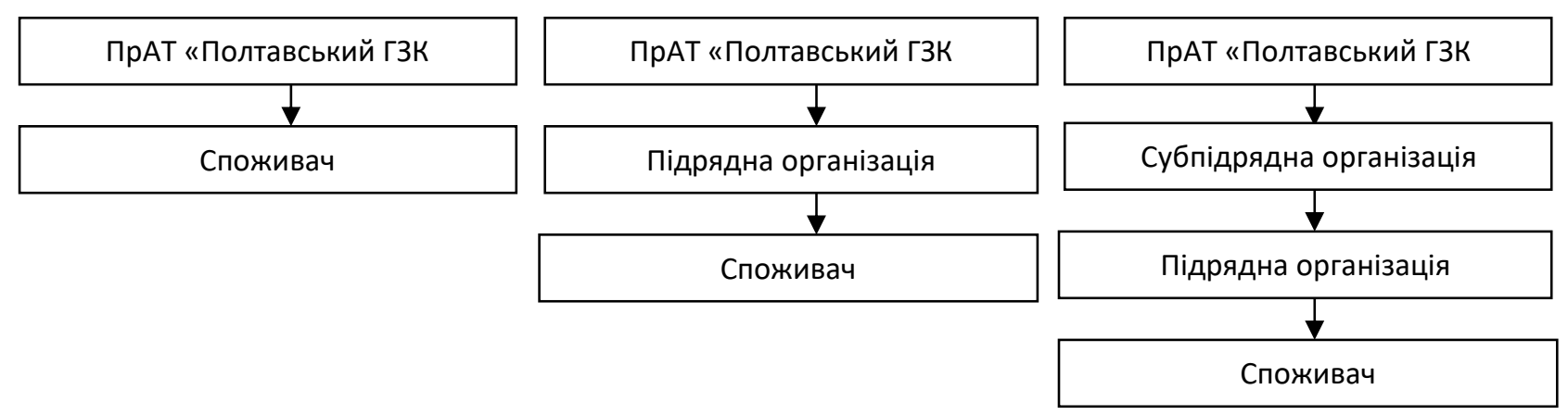

Рисунок 4 - Канали збуту ПрАТ «Полтавський ГЗК»

\section{Джерело: розроблено авторами}

Спираючись на результати SNW-аналізу, ПрАT «Полтавський ГЗК» надані рекомендації щодо удосконалення збутової діяльності підприємства на основі застосування інформаційно-програмних рішень. Запропоновано перший напрямок розвитку системи збуту - удосконалення у каналі прямих продажів юридичним особам. Одним із стратегічних завдань для ПрАТ «Полтавський ГЗК» $є$ збільшення обсягів виробництва основних цехів та підрозділів на $25 \%$. Це завдання потребує обробки великого обсягу даних про потенційних та поточних споживачів, а також основні аспекти їх взаємодії. Для розв'язання даного завдання актуальним i ефективним $\epsilon$ упровадження на підприємстві професійну CRMсистему, яка $є$ сучасною інформаційною технологією в питанні управління взаємодією із клієнтами. У якості оптимальної системи, яка відповідає цілям та задачам ПрАТ «Полтавський ГЗК» пропонується придбання програмного рішення «БІТ.CRM 8», до складу якого входять три функціональні модулі (табл. 5).

Таблиця 5 Функціональні можливості «БІТ.СRM 8»

\begin{tabular}{|c|l|}
\hline Функціональний модуль & \multicolumn{1}{|c|}{ Функції } \\
\hline Marketing Automation & $\begin{array}{l}\text { Планування маркетингової компанії, аналізу її результатів для кожної цільової } \\
\text { групи, продукту, регіону, управління комунікаціями, аналіз цільових груп і } \\
\text { формування цільовихаудиторій для маркетингових комунікацій. }\end{array}$ \\
\hline Sales Force Automation & $\begin{array}{l}\text { Прогнозування продажів, управління контактами, управління оперативною } \\
\text { роботою з клієнтами; управління можливостями, управління документацією, } \\
\text { аналіз циклу продажів, генерація звітності. }\end{array}$ \\
\hline Customer Service \& Support & $\begin{array}{l}\text { Управління центром обробки звернень клієнтів (Сall Сenter), управління } \\
\text { контактами із обслуговування, управління черговістю заявок клієнтів. }\end{array}$ \\
\hline
\end{tabular}

Джерело: складено авторами

Структурна схема програмного рішення «БІТ.СRМ 8» для ПрАТ «Полтавський ГЗК» наведена на рис. 5. 


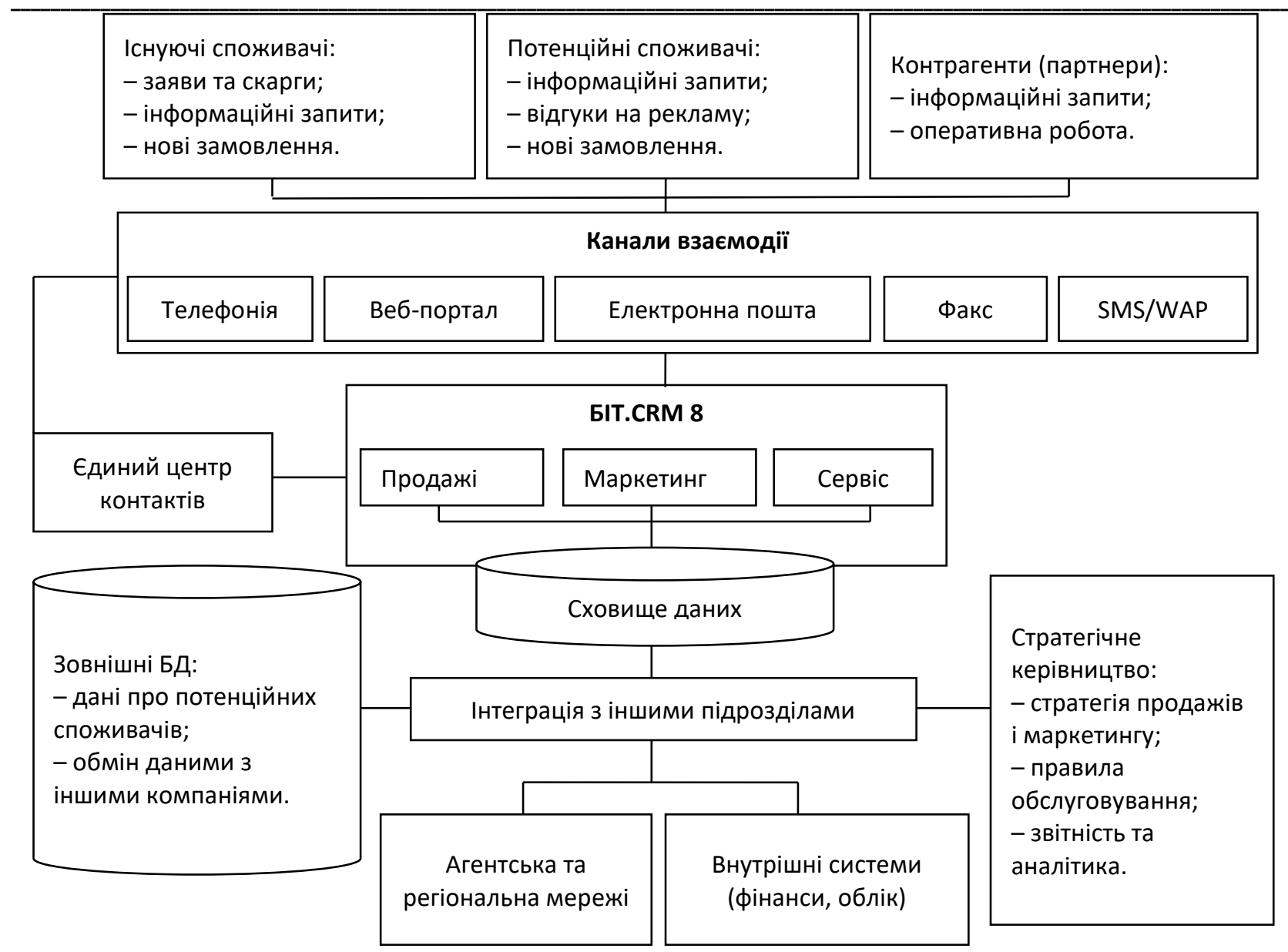

Рисунок 5 - Функціональні блоки «БІТ.СRM 8»

Джерело: розроблено авторами

Ефективність упровадження СRМ-системи очевидна. Перш за все, значну роль відіграє скорочення рівня товарних запасів. Другим важливим критерієм € зростання продажів за рахунок можливості надання споживачеві різних каналів продажів та пропозицій цікавих йому супутніх товарів, виходячи із «історії» покупок. Третій важливий критерій підвищення ефективності самих операцій, що досягається за рахунок скорочення часу транзакцій, від замовлення до приймання і відвантаження товару. Четвертим фактором $є$ зниження операційних витрат.
Тимчасові витрати персоналу ПрАТ «Полтавський ГЗК» на виконання дій, необхідних для роботи зі споживачем, при застосуванні СRM-системи скоротиться на 20-30\%. Тому співробітники при тій же чисельності виконають більший обсяг роботи, а отже, зможуть за той же час обробити більшу кількість споживачів та заробити пропорційно більший прибуток. Досвід реалізованих проектів із упровадження «БІТ.СRМ 8» показав наступні результати для ПрАТ «Полтавський ГЗК» (табл. 6).

\section{Таблиця 6 Економічні ефекти від упровадження «БІТ.CRM 8» на ПрАТ «Полтавський ГЗК»}

\begin{tabular}{|l|c|}
\hline \multicolumn{1}{|c|}{ Економічний ефект } & Значення, \% \\
\hline Збільшення обсягу продажів & $5-10$ \\
\hline Зниження виробничих і операційних витрат & 10 \\
\hline Зменшення складських запасів & 10 \\
\hline Зниження операційних та управлінських витрат & $15-20$ \\
\hline Економія оборотних коштів & $3-5$ \\
\hline Зменшення циклу реалізації продукції & $25-30$ \\
\hline Зниження комерційних витрат & $30-35$ \\
\hline Зменшення дебіторської заборгованості & $10-15$ \\
\hline
\end{tabular}

Джерело: складено авторами 
Наступним напрямком $є$ удосконалення каналу збуту продукції для фізичних осіб підприємства із використанням маркетингової комунікації. Доцільним $€$ просування корпоративного сайту підприємства за допомогою контекстної реклами та SEO-оптимізації. Контекстна реклама - це контекстно-залежні рекламні текстові оголошення або банери, які відображаються під рядком пошуку або у правій колонці пошукової системи за запитами користувачів. Орієнтовні витрати на упровадження даної рекомендації наведені у таблиці 7.

Таблиця 7 Витрати на створення контекстної реклами на ПрАТ «Полтавський ГЗК»

\begin{tabular}{|l|c|}
\hline \multicolumn{1}{|c|}{ Стаття витрат } & Сума, грн \\
\hline Створення контекстної реклами в «Яндекс» & 2000 \\
\hline Створення контекстної реклами в Google & 2000 \\
\hline Рекламний бюджет на рекламну кампанію в «Яндекс» і Google & 5000 \\
\hline SEO-оптимізація сайту & 3000 \\
\hline
\end{tabular}

Джерело: складено авторами

SEO-оптимізація $є$ найбільшим джерелом доступу до інформації в Інтернеті та основним методом просування сайту [11, с. 342]. За результатами проведеного статистичного дослідження даних пошукової системи Google, у середньому на місяць користувачі здійснюють близько п'яти тисяч запитів, пов'язаних із ринком залізорудної продукції. Ключовим показником ефективності контекстної реклами в Інтернет-маркетингу $\epsilon$ показник CTR, що виявляє частку користувачів сайту, які перейшли по рекламному оголошенню від загальної кількості осіб, які його побачили:

$$
\text { CTR }=\frac{\text { click }}{\text { impression }} * 100 \%
$$

де click - це кількість користувачів, які перейшли на сайт, од;

impression - це загальна кількість показів оголошень, од.

Середній показник CTR для даного ринку збуту становить $10 \%$. Це означає, що п'ять тисяч показів оголошень дадуть приблизно 500 відвідувачів на корпоративний сайт підприємства. Якщо середня кількість здійснених замовлень із 100 відвідувачів сайту буде рівна семи, то можна спрогнозувати, що у середньому буде з'являтися 35 нових клієнтів на місяць. Виходячи з практики ПрАТ «Полтавський ГЗК», сума середньої заявки від роздрібного клієнта становить 3000 грн, тому щомісячна виручка від реклами корпоративного сайту складе 105 тис. грн, що становить приблизно 1,3 млн грн/рік. Чистий прибуток від розширення ринків збуту на $25 \%$ із упровадженням "БІТ.СRM 8», виведений із урахування постійних та змінних витрат на виробництво складе 3 млн грн на рік. Спираючись на отримані дані, відбудеться збільшення річної виручки підприємства на 4,3 млн грн.

Висновки. Отже, одним із пріоритетних завдань удосконалення збутової діяльності підприємства $€$ застосування інформаційних рішень при поліпшенні ключових параметрів ії розвитку. У процесі дослідження були виявлені резерви зростання ефективності збутової діяльності ПрАТ «Полтавський ГЗК» та запропоновані рекомендації щодо їі удосконалення по кожному із існуючих каналів збуту. Проведений економічний аналіз показав високу ефективність від запропонованих рекомендацій, що полягає у додатковому збільшенні чистого дисконтованого прибутку. Основні теоретичні положення та висновки дослідження можуть бути використані для подальшого вивчення питань, пов'язаних із організацією інформаційного забезпечення поточної виробничої діяльності металургійного підприємства та удосконаленням збутової діяльності із застосуванням інформаційних технологій.

\section{Література:}

1. Терент'єва Н. В. Принципи та функції управління збутовою діяльністю. Вісник Запорізького національного університету. 2016. № 1 (29). С. 127-138.

2. Пєтухова О. М., Стасішена К. В. Удосконалення збутової діяльності підприємства. Ефрективна економіка. 2018. № 2. С. 1-8.

3. Сазонець О. М. Інформаційні системи і технології в управлінні зовнішньоекономічною діяльністю: навч. посіб. / за ред. О. М. Сазонець. Київ : ЦНЛ, 2014. 256 с.

4. Матвієць О. В., Кошівська М. В. Збутова діяльність як складова частина господарської діяльності підприємства. Модеrn Economics. 2018. № 11. C. 116-121. https://doi.org/10.31521/modecon.V11(2018)-19.

5. Нестеренко С. С., Кутліна І. Ю. Сутність збуту в системі маркетингу підприємства. International Scientific and Practical Conference «World Science». 2016. №1 (5). С. 76-79.

6. Ключник А. В., Білозерцева І. О. Теоретичний аналіз поняття «збуту» та його функцій. Науковий вісник Херсонського державного університету. Сер.: Економічні науки. 2014. 6(2). С. 188-191.

7. Репіч Т. А. Удосконалення функціонування каналів розподілу за рахунок взаємодії маркетингової та логістичної складової. Інвестиції: практика та досвід. 2018. №3. С. 61-65. 
8. Орлова К. О., Дорожкіна Г. М., Сакун Л. М. Оцінка ефективності зовнішньоекономічної діяльності металургійного підприємства за умов фінансової кризи. Приазовський економічний вісник. 2018. 5 (10). С. 15-21.

9. Сухомлин Л. В., Різніченко Л. В., Орлова К. О. Забезпечення сталої конкурентної позиції підприємства за рахунок ефективного управління його ресурсним потенціалом. Проблеми системного підходу в економіці. 2018. 3 (1). С. 109-115.

10. Shtal T. V., Buriak M. M., Amirbekuly Y., Ukubassova G. S., Kaskin T. T., Toiboldinova Z. G. (2018). Methods of analysis of the external environment of business activities. Espacios, 29, 12, 22-31.

11. Egria, G. \& Bayrak, C. (2014). The role of search engine optimization on keeping the user on the site. Procedia Computer Science, 36, 335-342. https://doi.org/10.1016/j.procs.2014.09.102.

\section{References:}

1. Terentjeva, N. V. (2016). Principles and functions of management of marketing activities. Bulletin of the Zaporizhzhya National University, 1 (29), 127-138 [in Ukrainian].

2. Petukhova, O. M. \& Stasyshena, K. V. (2018). Improvement of sales activity of the enterprise. Electronic scientific special edition "Effective economy», 2, 1-8 [in Ukrainian].

3. Sazonets O. M. (2014). Informacijni systemy i tekhnologhiji v upravlinni zovnishnjoekonomichnoju dijaljnistju. Kiev: CEL [in Ukrainian].

4. Matviyets, O. V. \& Koshivska, M. V. (2018). «Sales management as part of economic activity of enterprise». Modern Economics, 11, 116-121[in Ukrainian]. https://doi.org/10.31521/modecon.

5. Nesterenko, S. S. \& Kutlina, I. Y. (2016). The essence of sales in the marketing system of the enterprise. International Science and Practical Conference «World Science», 1 (5), 76-79 [in Ukrainian].

6. Klyuchnik, A. V. \& Bilozertseva, I. O. (2014). Theoretical analysis of the concept of «sales» and its functions. Scientific Herald of Kherson State University. Economic Sciences, 6 (20), 188-191 [in Ukrainian].

7. Repich T. A. (2018). Improving the functioning of distribution channels through the interaction of the marketing and logistics component. Investments: practice and experience, 3, 61-65 [in Ukrainian].

8. Orlova, K.O., Dorozhkina, H.M. \& Sakun, L.M. (2018). Evaluation of foreign economic activity efficiency of the metallurgical enterprise under financial crisis. Priazovsky Economic Bulletin, 5 (10), 15-21 [in Ukrainian].

9. Sukhomlyn L. V., Riznichenko L. V. \& Orlova K. O. (2018). Ensuring of the enterprise competitive position through the efficient management of its resource potential. Problems of systemic approach in the economy, 3 (1), 109-115 [in Ukrainian].

10. Shtal, T. V., Buriak, M. M., Amirbekuly, Y., Ukubassova, G. S., Kaskin, T. T. \& Toiboldinova, Z. G. (2018). Methods of analysis of the external environment of business activities. Espacios, 29, 12, 22-31.

11. Egria, G. \& Bayrak, C. (2014). The role of search engine optimization on keeping the user on the site. Procedia Computer Science, 36, 335-342. https://doi.org/10.1016/j.procs.2014.09.102.

Ця робота ліцензована Creative Commons Attribution 4.0 International License 